\title{
PILLARS OF INDIAN ECONOMY IN COVID-19: COMPREHENSIVE STUDY OF FARMING \& AGRO BASED INDUSTRY
}

\author{
1 Vishal Varma, *2 Prof. (Dr.) Ravi Kumar Goyal \\ 1 Entrepreneurship Skills, Nirwan University Jaipur. \\ *2 Pro-President, Nirwan University, Jaipur, Rajasthan. \\ *2 Email: goyalravikumar5@gmail.com
}

\begin{abstract}
The country was under lockdown from more than two months due to COVID-19. In this crisis, the farmers have not allowed food security to be endangered. Moreover, they have increased food production despite all the obstacles. Right now, farmers are facing many obvious and climatic problems. Prime Minister of India has said that we have to convert this crisis into opportunity. The solution to farmer's problems is necessary, to make the country Atmanirbhar Bharat and to take it rapid fast on the path of progress.
\end{abstract}

The outbreak of this epidemic has come at a time when the harvesting of Rabi crops had already started. However, taking necessary steps, Ministry of Agriculture has worked with all agencies of selling and buying agricultural products, units notified by the state governments, farmers and agricultural labourers along with machines used in harvesting and sowing and agro-horticulture exempted from and out of state. In addition, the All India Transport Call Centre was launched to remove bottlenecks in the movement of seeds, pesticides, fertilizers and fruits, vegetables, milk, eggs, fish and other perishable agricultural products

Keywords: Pandemic, Atmanirbhar bharat, Agro-horticulture, Rabi crops, Kharif Crops, farming, Agriculture

\section{INTRODUCTION}

Along with the fight against the Corona epidemic, India has also embarked on a renewed economic reconstruction with a resolve for self-sufficiency. In view of the problems arising in the Corona period, the government has started implementing it while explaining the economy afresh. It is based on the principle of 'self-reliance' and Swadeshi, in which special attention will be given to the workers. Just as workers have a wide range of skills, the products have specialties in different geographical regions of the country.

Although the government has already started the 'One District One Product' program, its utility has increased after Corona. To rebuild the country's economy and give it a new direction, the government has announced an economic package of 20 lakh crore rupees, India's agri export jumps 23.24\% during March-June 2020 despite pandemic, (ICAR 2020). 
Some industry approximation indicates that online retail grocery probably report for much lower shares at $0.1 \%$ (Narayanan and Saha 2020a).

If we look at the agricultural system of developed countries not only in India, then it is clear that the agricultural system of any country cannot run without government protection and huge subsidies. Along with this, the current situation has been affected in the era of epidemics, which is not positive. Since there are maximum employment opportunities available in the agriculture sector in our country, it is important to protect it on priority basis, (ICRI 2020).

The APMC Act was introduced in the 1950s and the Minimum Support Price System in 1966 to provide protection to the farmers of India, although it is important that even the minimum support price system was not legalized. In 1935, the then US President Franklin D. Roosevelt created a price support policy to protect his farmers from the global recession. Even today, the USA is subsidizing more than $\$ 800$ billion, including $\$ 210$ billion of new subsidies. All this is also a serious economic crisis on America's agricultural system in the Corona era, this year; American farmers have incurred a debt of 425 billion dollars (USDA 2020). But the disaster caused by the Corona epidemic in India has turned into the opportunities by farmers. A detailed analysis and possible solution on the state of agriculture, yield, farming and cottage industry with the upcoming challenges during this global epidemic is suggested in this research report.

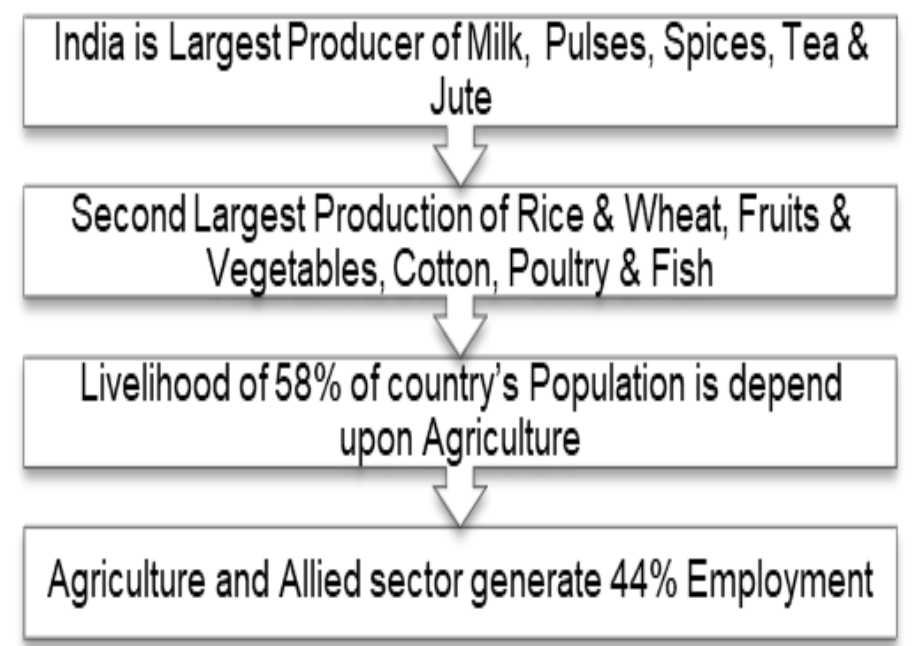

Figure 1. Agriculture Hierarchy

\section{DISTINGUISH ISSUES THAT HAVE COME FORTH IN THE POST- COVID-19 ERA}

Following issues are matter of concern for farming and cottage industry along with employment.

- Due to the lockdown, Corona epidemic and adverse weather, the mandi's and local markets are not opening up systematically and due to non-timely payment of sugarcane farmers by sugar mills the cash crisis has increased in front of farmers. Wholesale agricultural markets 
and mandis, became risk of exposure domain for virus transmission leading to intermittent mandi closures (Rawal and Kumar 2020; Ramakumar 2020).

- Workers from the provience of Punjab, Haryana, Himachal, Uttarakhand and Uttar Pradesh, and from Maharashtra, Gujarat, have largely returned to their homes in agrarian states like eastern Uttar Pradesh, Bihar, Madhya Pradesh, Odisha and West Bengal, largely due to the Corona crisis. Farmers of these states have suffered due to the workers' movement to their homes.

- The concern of farmers remains due, to not having any labour for transplanting paddy. Farmers are also facing trouble in collecting vegetables from crops. Sugarcane harvesting and chipping also require workers. The existing grounds indicate that the notifications of the centre government relating to agrarian activities among the lockdown were profoundly reactive and were often not logical with actions already been implemented by the states (Narayanan and Saha 2020b).

- Given the uncertainty of the Corona crisis, the crushing season from October for sugarcane farmers can be difficult. Workers who have returned home amidst an atmosphere of fear might return by October 2020; it is difficult to say right now. From June 2020 onwards, apple harvesting and packaging in Himachal and horticulture sector like mango, litchi, orange etc. will have to face the problem of workers. One of the analysis prescribed that an overwhelming majority (Almost 85\%) who recognized themselves as agrarian workers were either not capable enough to harvest, could not sell or sold at reduced prices (Azim Premji University 2020).

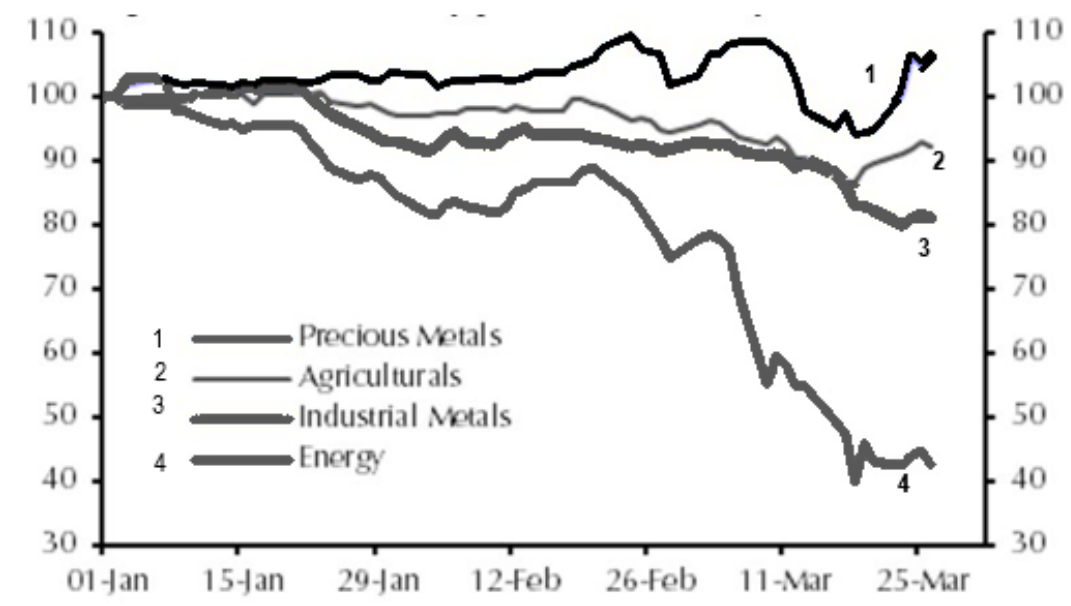

Figure 2 Global commodity price indices, January to March 2020 (Source: Capital Economics.)

\subsection{Women in Agriculture}

The Economic Survey of India (2017-2018), conducted by Government of India explained that the agrarian sector in India is experiencing feminization. Women of the nation only possess $12 \%$ of the total farming land; around $73 \%$ of rural females employed in agriculture 
and allied activities. In the era of shrinking employment chances in agriculture, male have diversified into the non-farm sectors in rural and sub rural areas, while male outmigration has came forth as a significant livelihood scheme. In this context, as Kulkarni (2020) signalizes many of these parameters also impact on a large constituency of female (and tenant) farmers to resist for themselves, since they are less likely to be registered for institutional procurement and tend to not have title to land.

The World Bank approximates that India is having around 140 million internal migrant labourers. Along with less non-farm sector availability of employment and reverse migration of men back to villages, more male labours will be in field to face agrarian work. Almost 50 million migrant labourers from various parts of the country have returned back to their native places from industrial belts after the nationwide lockdown. This probably could impact female's working as farmers and chances reversing the gain achieved over the past couple of years. Since male back in the villages, female probably forced to join the less paid and most lowly agrarian tasks. Their wage ratio may decrease further. As men are now locally available, they may have more engagement in the marketing of their products and so command the money too. Hierarchy of Self-help group (SHG) for women and other organizations will have to contribute a smart role in negotiating for women workers.

Cooperatives, SHG's and rural committees could also play an important role in organizing for the supply of intakes and ascertain aggregation with marketing of products. Other organizations and government institutions should get up desirable capacity-building and need identification processes to help women retain their hold in field. Task allotment under National Rural Employment Guarantee Scheme should also give decent delegacy to women.

\subsection{Farmers' Producer Organizations (FPOs)}

Amendment in Agriculture Produce Market Committee Act-2003 and the Essential Commodities Act-1955 unfold fabulous market dimensions for FPOs. When states will coordinate their guidelines \& policies with the central government of India's ordinance, then this can definitely welfare the buyers and permit them to purchase from anywhere-This surely indicates multiple choices and dimensions for farmers.

The increased assurance of corporate houses in FPOs has increased the ambit for contract farming and improved corporate interests in contract base farming. However, to ascertain that stakeholders maintain contract guidelines, terms and conditions, it is essential to constitute contracts to incorporate insurance-oriented with safety provisions, along with planning that permit farmers to part any unprecedented gains from market fluctuations. However, it is also cognizant to frame conflict solving hierarchy in the context of arbitration institutions at the district and sub-district levels, which must be approachable, easy and cost-effective for farmers and contracting entities.

\subsection{Objectives of the Study}

- To analyze the agriculture $\&$ cottage industry activities during pandemic.

- To evaluate the production of food grain farmers, horticulture \& floriculture farmers. 
- To propose contemporary strategies for and migrant labourers.

- To study Livestock, animal husbandry and dairy in context of employment.

\section{DIMENSIONS OF RESEARCH METHODOLOGY}

The study is empirical in nature. Following points will be discussed thoroughly during the paper.

\subsection{Natural Disparities and Migrant Workers}

About 60 percent of the country's population depends on agriculture. Early this year, grasshoppers attacked crops. This was the largest locust attack in 25 years. Not only this, from sowing to harvesting to hailstorm, heavy rains and strong winds, crops like wheat, lentils, mustard, peas etc. were severely damaged in Punjab, Haryana, Rajasthan and Uttar Pradesh. Despite this, the production of wheat has gone up by 11.37 million tonnes or 9.7 percent this year compared to 10.36 million tonnes last year. Similarly, production of Bengali gram also increased by 1.07 million tonnes i.e. 8 percent as compared to 0.99 million tonnes last year. Oilseeds also increased by 0.95 million tonnes, or 2.7 percent this year, compared to 0.92 million tonnes last year.(Estimate of production of Food Grains 2018-19 and Advanced Estimate of production of Food Grains 2019-20, Department of Agriculture, Cooperation \& Farmers Welfare)

\subsection{Impact and Resolution of Epidemics on Livestock, Trade and Products}

The biggest loss in lockdown has been due to the destruction of supply chain management of fruits-vegetables, flowers, milk, poultry, fisheries etc. During this crisis, the floriculture farmers have suffered 100 per cent and fruit and vegetable growers suffered more than 50 per cent. Animal husbandry is an important part of the agricultural sector. Farmers get about 13 percent of the total income from animal husbandry. In this lockdown, cattle, cattlemen are the biggest losers due to the closure of restaurants, hotels, dhabas, sweet shops and markets, and even transportation has come to a standstill.

Table 1: Impact and Resolution of Epidemics on Livestock, Trade and Products

\begin{tabular}{|c|c|c|}
\hline Sector & Impact Duration-Short Term & Impact Duration: Medium \& Long \\
\hline $\begin{array}{c}\text { Agriculture } \\
\text { Input }\end{array}$ & $\begin{array}{c}\text { The supply of input was disrupted as the } \\
\text { movement of stock was not possible; sale of } \\
\text { fertilizers had increased with good monsoon } \\
\text { this resulted fabulous Rabi crop. }\end{array}$ & $\begin{array}{c}\text { The availability of inputs for Kharif } \\
\text { crops significantly improved due to } \\
\text { easing up lockdown restrictions. }\end{array}$ \\
\hline $\begin{array}{c}\text { Around 50 million migrant labors had } \\
\text { returned during lockdown period. North- } \\
\text { Labours/Farm }\end{array}$ & $\begin{array}{c}\text { Western states like Rajasthan, Punjab and } \\
\text { the other side eastern part of the country like } \\
\text { Bihar, Jharkhand, West Bengal and some } \\
\text { part of Uttar Pradesh had surplus of labours. }\end{array}$ & $\begin{array}{c}\text { The situation remains the same, so } \\
\text { Kharif sowing might be affected in } \\
\text { Rajasthan, Punjab \& Hariyana due to } \\
\text { shortage of labors. }\end{array}$ \\
\hline $\begin{array}{c}\text { Farm } \\
\text { Mechanization }\end{array}$ & $\begin{array}{c}\text { Tractor sales have declined in first quarter } \\
\text { of FY 2020-21. }\end{array}$ & $\begin{array}{c}\text { Tractors sales had risen up in second } \\
\text { quarter of FY 2020-21 for potential }\end{array}$ \\
\hline
\end{tabular}




\begin{tabular}{|c|c|c|}
\hline & & $\begin{array}{l}\text { farmers where labor shortage } \\
\text { occurred, while the figure of sales } \\
\text { remain unchanged where the surplus } \\
\text { labor is available. }\end{array}$ \\
\hline Dairy & $\begin{array}{l}\text { The impact of COVID-19 on this sector was } \\
\text { moderate, Institutional demand reduced due } \\
\text { to lockdown but individual demands } \\
\text { remains unchanged and some areas shown } \\
\text { increased individual demand as well. }\end{array}$ & $\begin{array}{l}\text { Dairies minimized the loss by } \\
\text { converting milk into skimmed milk. }\end{array}$ \\
\hline Fisheries & $\begin{array}{l}\text { Impact of COVID-19 on this sector was } \\
\text { moderate in the terms of stocks and traders. } \\
\text { The supply of stocks had been affected. }\end{array}$ & $\begin{array}{l}\text { Since most of the units involved in } \\
\text { this sector having good amount of } \\
\text { storage capacity. So the supply and } \\
\text { trading is expected to bounce back in } \\
\text { third quarter of FY 2020-21 }\end{array}$ \\
\hline Floriculture & $\begin{array}{l}\text { Substantial loss due to sudden fall in } \\
\text { demand }\end{array}$ & $\begin{array}{l}\text { Many farmers moved away from } \\
\text { floriculture. Festival season from } \\
\text { September-November boosted up the } \\
\text { demand. }\end{array}$ \\
\hline Poultry & $\begin{array}{l}\text { This sector did face significant loss due to } \\
\text { reduced institutional demand and supply and } \\
\text { the prices of chicken fell by around } 20-25 \%\end{array}$ & $\begin{array}{l}\text { Poultry farm houses reduced their } \\
\text { sizes and started other business } \\
\text { activities along with poultry. }\end{array}$ \\
\hline Vegetables & $\begin{array}{l}\text { The impact of COVID-19 on this sector was } \\
\text { initially high due to blockage in } \\
\text { transportation and supply. This impact was } \\
\text { shown higher in rural areas. }\end{array}$ & $\begin{array}{l}\text { The present scenario provided a huge } \\
\text { opportunity of employment with move } \\
\text { away from APMC regime after } \\
\text { implementation of Agriculture } \\
\text { Reforms Bills- } 2020\end{array}$ \\
\hline
\end{tabular}

Source: www.mygov.in

The country produces about 500 million litres of milk daily. Out of this, 200 million litres of milk are consumed in households, the remaining 300 million litres of milk comes in the markets through cooperatives and private dairy companies. Cooperatives did provide relief to dairy farmers by taking 8 percent more milk than their capacity, but under these, less than 25 percent of the country's milk producers are covered only. In many places, these cooperatives reduced the prices of milk by Rs 5 per litre, while private dairy companies bought milk at a reduced rate of Rs 10 per litre. By buying cheaper milk, these companies have retained its powder (DARE-ICAR 2019-20).

When the production of milk decreases in the summer season, then they will make profit by making milk from this powder. The second problem of milk producers is that due to the shutdown of the industry, animal feeds have become expensive, due to which the cost of milk production has increased considerably. Overall, milk producers are at a disadvantage, but due to the organized dairy industry, there has not been a situation like throwing of milk. 
Similarly, the poultry sector is about Rs 1.25 lakh crore. The poultry and fisheries industry also need to be strengthened like dairy to strengthen the supply chain, 'The COVID-19 pandemic \& Indian Agriculture: A Note’ by M.S. Swaminathan Research Foundation.

\subsection{Features of Agro-Based Systems}

Despite all the worse conditions, farmers have worked hard in the preparation of kharif farming. Farmer is busy collecting seeds, pesticides and fertilizers by even taking loans from moneylenders. This shows the dedication and affection towards the nation. Also, the good thing is that before the lockdown most of the sugarcane supply was given to the mills and about 20 per cent of the fields had sugarcane left, which the farmers are handling with mutual support. Small and marginal farmers often sow sugarcane through this Method. Therefore, sugarcane farmers will have to concentrate on an alternate system of sugarcane harvesting.

Cost of food in India increased 11.07 percent in October of 2020 over the same month in the previous year. It seems the maximum food inflation rate since January and in front of the festival time. Costs of pulses climbed up $18.34 \%$, meat and fish $18.7 \%$, egg $21.81 \%$, and vegetables $22.51 \%$.

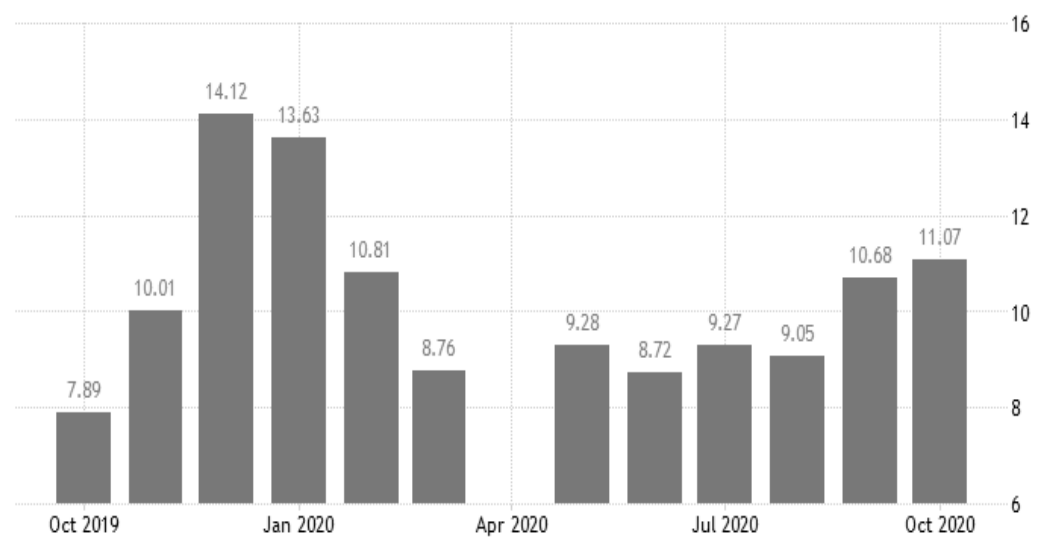

Figure 3: Trading economics, Ministry of Statistics and Programme Implementation

(MOSPI)

\subsection{Economic Package: Bharat Nirman Package}

The government has insisted on rebuilding the nation instead of giving cash relief. A number of steps have been taken to make the rural economy self-sufficient in a real sense. Due to many years of faulty economic policies, the employment opportunities are limited to only a few metros and big cities. The government package is not a relief package in this case; it is a package of building the nation. Many more decisions have been made with it, which shows the vision of rejuvenating India.

The most important thing in the package is the emphasis on agrarian reform. The fact to remember here is that agriculture bears the burden of 60 per cent of the population but the contribution to GDP is only 15 per cent, so in many respects it is bigger than the 1991 Manmohan-Rao economic-reforms. Cultivation was completely untouched by the then reforms. 
The second feature of the Bharat Nirman Package is the emphasis on medium and small-scale industries. The government defined micro, small and medium-scale industries. It has often been seen that small-scale industries did not want to grow up in fear of inspector raj. The government made it clear that the regulation will not change even if the size of the industries increases. If we look closely, micro and small-scale industries are largely related to agriculture. This will also help in building a market for farmers.

\section{LABOUR REFORMS BILLS 2020}

Indian Parliament on September 2020 approved three key labour reform bills including the Occupational Safety, Health and Working Conditions Code, 2020, the Industrial Relations Code 2020 and the Code on Social Security, 2020. 29 central labour laws have been statute into four broad codes as expected by the government of India under labour reforms to improve ease of doing business and render universal social security to workers as well.

The main features of labour Bills 2020 are:

- These labour bills will provide social security and proper environment along with right remuneration at workplaces to 50 Crore workers, adding that the focused aim of these laws is to bring all form of facilities and healthy environment to workers.

- The Industrial Relations Code relating to step-up in the doorstep for downsizing, shut down or lay off for a enterprise (without the consent of government) to 300 workers from existing 100, large number of enterprises don't increment their number of workers more than 100 which results in a hike in informal employment

- (Parliamentary Standing Committee on Labour, Report 2020)

- Rajasthan found a betterment in job origination and an unprecedented reduction in the number of cases of dismissal of staff, (Economic Survey of India, 2019).

- A code has mentioned about the provision of providing appointment letters to workers, that now a worker would get at least 50 per cent of the penalty in addition with compensation in accidental cases.

- There will be no threshold limit for implementation of the code as it will cover all organisations even if it will have one labour. Fixed-term employment would get all benefits at par with regular employees.

- Provision of 14 days notice before going for a strike would help management and workers to resolve differences.

- The threshold for closure, retrenchment and layoff without government permission for units having up to 300 employees will help in attracting investors and creating jobs.

- On limiting the definition of migrant labours, If the salary of workers is less than Rs 18,000, they would come under it and they will be able to avail the welfare schemes of the government. (Labour Bills 2020, Report of the Expert Committee on Determining the Methodology for Fixing the National Minimum Wage, Ministry of Labour \& Employment, Government of India)

Most of the cottage and small-scale industries have seasonal or cyclical character. In such a situation, the current labour laws were irrelevant and only play a negative role in industrial development. Apart from this, by providing credit lines at a subsidized rate of 3 lakh crores, entrepreneurs have been given golden opportunities to set up industries. The specialty of the 
Bharat Nirman Package is that it has an emphasis on integrated development. That is, if the agriculture sector has been reformed, then steps have also been taken for cottage and smallscale industries. These two sectors are interlinked.

\section{LAND, LABOUR AND CAPITAL MATRIX}

Now, to encourage industries, attention has been given to all three means of production land, labour and capital.

- Entrepreneurs can have cheap labour, technology, land, cheap capital and market.

- It has been announced to create 10 mega cluster zones, which will establish industrial units on a large scale and employment will also be available in the remaining cities near the village. This will prevent the exodus of workers.

- A special window of Rs 30,000 crore has been given to non-banking companies to tackle the liquidity problem.

MGNREGA budget has been increased to one lakh crore for rural development. With this, there is a system to get money in the hands of landless labourers. Corporate tax reforms have already been done. It is now the most competitive in Asia. In this scenario we have not discussed the incentives of the state. Many states are offering stamp duty exemption, cheaper land, exemption on electricity tariff, and also subsidy on interest, Economic Survey of India 2018-19.

The Government of India has prepared a pool of 20 million square feet industrial land in eight cities of the country. Due to this, big industries will not have to fight for land acquisition. In the last five years, more than 1000 old laws have been abolished.

The Bharat Nirman package has also tried to overcome the trend of urgency; actually farreaching steps have been taken for future growth. Vocal indigenization is the soul of the local. An attempt has been made in this package to remove the imbalance between the city and the village.

\section{STRATEGIES TO IMPROVE EMPLOYMENT WITH FARMING \& COTTAGE INDUSTRY}

India lives in villages and without making the village self-sufficient, 'self-sufficient India' cannot be imagined. The situation exposed to the country due to Covid-19, some improvement will have to be made in the agricultural system. To make the village selfsufficient, firstly a road map will have to be prepared to scale down the dependency of the village on the industry. In order to secure the food security of the village, according to the coordinated farming system, the agricultural system will have to be repaired so that adequate fodder can be made for the livestock and animals etc. for the rural population. Below is unemployment rate of India for 2018-2020 data. 


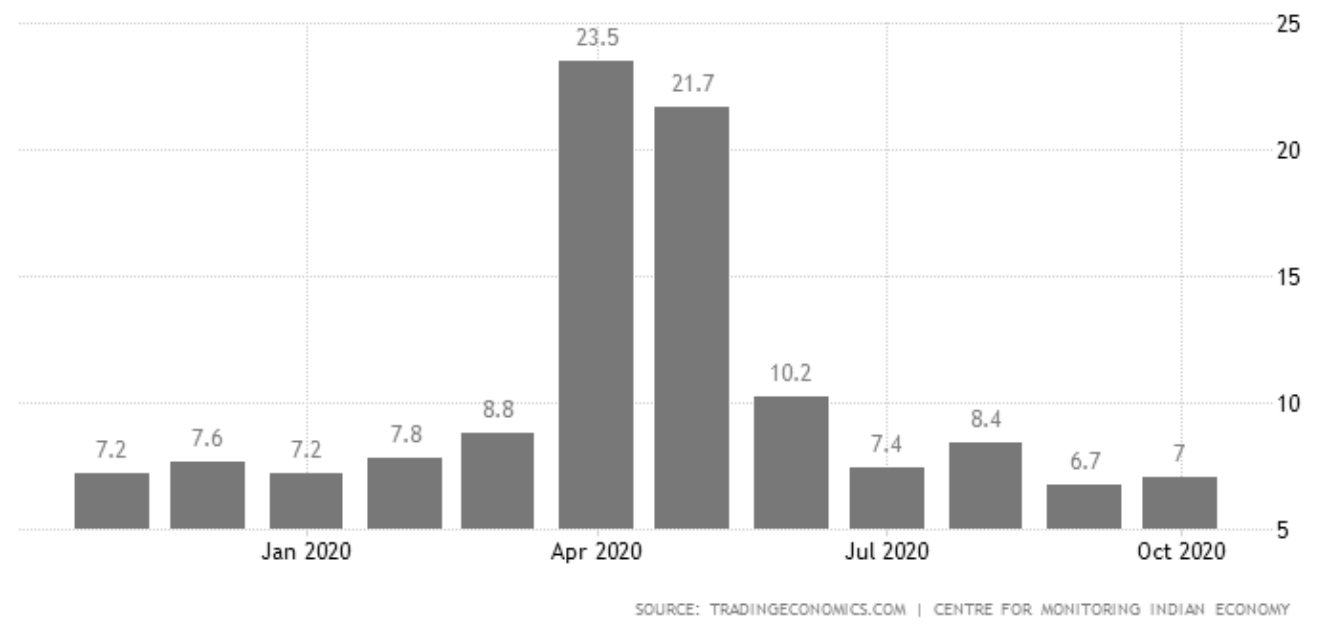

Figure 4: Trading economics, Centre for monitoring Indian Economy

Animal husbandry will also have to be promoted, so that farmers and landless people get income. For this, adequate arrangements will have to be made for the feed of animals in this crop cycle. This will reduce dependence on markets for food and make villages selfsufficient.

About 60 percent of the village's population is dependent on agriculture, while 40 percent of the population is landless and depends on small scale industries for livelihood and also contributes to farming. In terms of agriculture, India is a region with a different agricultural climate. Therefore, the coordinated farming system may have different formats according to the agro-climatic zones of the entire country.

Additional arrangements of employment will also have to be made for the people returning to the village during the crisis. Every person living in the village will get a job, for this, along with agriculture; a well-organized marketing network will have to be created for food processing, value addition and to make their products directly accessible to the customers. We have to move towards making the village, district, state and country Atmanirbhar Bharat. Therefore, three things have to be kept in mind while planning for self-sufficiency:

- The density of population of that region.

- The structure of agricultural production and

- Water conservation in that area. Food and water are the basic needs, so strengthening food security, there should be enough food collection for at least one year and water conservation and storage will have to be done during rainy season.

\section{CONCLUSION}

Despite the epidemic today, only due to farmers, there is no shortage of food grains in India. It is time to analyse its food security system and remove the flaws present in it. The government and the administration will have to focus on arranging purchasing from farmers' fields, building sufficient number of warehouses, cold stores and setting up food processing 
and packaging units in the district level to strengthen food security. This will capable the farmers to obtain the contemporary price for their products and additional employment opportunities will be created.

Also, every year there must be ban on waste of thousands of tonnes of food grains. In the time of this crisis, the supply chain has been exposed to many flaws, which need attention. We will have to abolish all such laws which are hindering the agricultural sector and increasing the income of farmers. Taking lessons from the lockdown, the governments of Madhya Pradesh and Uttar Pradesh have announced some amendments to the Mandi Act. Now farmers will be able to sell their crop to any person or body without market. If you want, you can give crops at the minimum support price in the mandis as before. Prime Minister has also asked states to implement basic reforms in agriculture.

We know that COVID-19 is not going to get rid of quickly, but the lockdown mechanism cannot be kept for long. Hence the central government is gradually lifting the restrictions imposed on public life. It is a matter of satisfaction that the government has taken all steps while remaining sensitive towards all sections of the society. The interests of farmers have also been kept in constant consideration. The coming time is not easy for all of us. COVID19 has destroyed our economic life. There is no doubt that agriculture is the only sector that can give economic momentum even in emergency situations. Now the time has come to focus on the overall development of the people who returned to the village during the lockdown by connecting them to agriculture and cottage industries. It is the responsibility of all of us to make the government aware of the problems of farmers from time to time so that appropriate decisions can be taken in their interest. The Prime Minister's recent declaration of an Atmanirbhar Bharat, India will prove to be a decisive step in the war against Corona, only when all from bottom to top play their role honestly.

\section{REFERENCES}

[1]. Agricultural Statics at a Glance 2018. (Department of Agriculture, Cooperation \& Farmers Welfare, Annual Report 2018-19). Annual Report | Department of Agriculture Cooperation \& Farmers Welfare $\mid$ Mo A\&FW| GoI (agricoop.nic.in)

[2]. Annual Report 2019-2020, Annual Report 2018-19, Annual Report | Ministry of Labour \& Employment

[3]. Azim Premji University. 2020. COVID-19 Livelihoods Survey: A Compilation of Findings.

[4]. https://cse.azimpremjiuniversity.edu.in/wp-content/uploa ds/2020/06/Compilation-offindings-APU-COVID-19-Livelihoods-SurveyFinal.pdf.

[5]. DARE-ICAR Annual Report 2019-20, DARE-ICAR Annual Report 2018-19 ICAR. https://icar.org.in/sites/default/files/AR-2019-20-English-Final.pdf

[6]. Economic Survey (indiabudget.gov.in)

[7]. Kulkarni, Seema. 2020. Locked in a crisis: Concerns of rural women. Economic and Political Weekly 55(23): 15-1806. 
[8]. Narayanan, Sudha, and Shree Saha. 2020a. Urban food markets and the lockdown in India. Working Paper WP-2020-017.Indira Gandhi Institute of Development Research. WP-2020-017.pdf (igidr.ac.in)

[9]. Narayanan, Sudha, and Shree Saha. 2020b. One step behind: The Government of India's response vis-à-vis agriculture during the lockdown. Review of Agrarian Studies. RAS | One Step Behind: The Government of India and Agricultural Policy During the Covid-19 Lockdown

[10]. Ramakumar, R. 2020. Farmers are at their wit's end. The Hindu, April 7, 2020.

[11]. Rawal, Vikas, and Ankit Kumar. 2020. Agricultural Supply Chains during the COVID-19 Lockdown: A Study of Market Arrivals of Seven Key Food Commodities in India. SSER Monograph 20/1, Society for Social and Economic Research.

[12]. https://labour.gov.in/sites/default/files/Commitee_on_Determination_of_Methodolo gy.pdf

[13]. India: COVID-19 in India - GOI's Economic Package for Self-Reliant India - Food and Agriculture Items | USDA Foreign Agricultural Service. DownloadReportByFileName (usda.gov)

[14]. The Covid-19 Pandemic and Indian Agriculture: A Note | M S Swaminathan Research Foundation (mssrf.org)

[15]. World Bank. 2020. COVID-19 Crisis Through a Migration Lens. Migration and Development Brief No. 32; World Bank Washington-DC. https://openknowledge.worldbank.org/handle/10986/33634 License: CC BY 3.0 IGO. World Bank Document. 